TAO, Vol. 16, No. 1, 95-111, March 2005

\title{
Calcareous Nannofossils and Variation of the Kuroshio Current in the Okinawa Trough During the Last 14000 Years
}

\author{
Xin, $\mathrm{Su}^{1, *}$, Kuo-Yen, $\mathrm{Wei}^{2}$ \\ (Manuscript received 14 May 2004, in final form 8 November 2004)
}

\begin{abstract}
A quantitative census study on calcareous nannofossils from sediments of Site 1202 recovered by ODP Leg 195 and surface sediments from the East China Sea was carried out to obtain a high-resolution nannofossil record of the change of the Kuroshio Current during the late Quaternary.

Two nannofossil ratio indices were designed and employed in this study: (1) ratio of Florisphaera profunda against $F$. profunda, Emiliania huxleyi and Gephyrocapsa oceanica (F-EG ratio) as a nannofossil proxy of the Kuroshio Current, (2) ratio of $G$. oceanica against $F$. profunda and $E$. huxleyi and G. oceanica (G-FE ratio) as a proxy of near-coast environment. Results from the 14 surface nannofossil samples demonstrate that the F-EG ratio is $>15 \%$ in the assemblage lying directly under the main route of the Kuroshio Current, whereas it is very low $(<\mathbf{1 0 \%})$ in sediments off the current. High ratios G-FE ( $>30 \%$ ) were seen from all samples on the East China Sea continental shelf or from near-coast cores.

Down hole nannofossil record from the top $60 \mathrm{mbsf}$ sediment interval at ODP Hole 1202B reflects the change of the Kuroshio Current in the last glacial and postglacial period since $14 \mathrm{ka}$. Extreme low F-EG ratio together with very high G-FE ratio at Hole 1202B during the time of the latest Pleistocene and the earliest Holocene suggest the absence of the Kuroshio Current in the area studied. The event of intrusion of the Kuroshio Current was clearly recorded by a dramatically increase of F-EG ratio and notably a reduction in the G-FE ratio around $9 \mathrm{ka}$. Furthermore, based on the variation of the F-EG ratio and $\delta{ }^{18} \mathrm{O}$ of planktonic foraminifera Neogloboquadrina dutertrei, variation of the Kuroshio Current in the Holocene shows three long-term cycles (with a periodicity of $\sim 3000 \mathrm{yr}$ ).
\end{abstract}

\footnotetext{
${ }^{1}$ Center of Marine Geology, China University of Geoscienes, Beijing, China

2 Deparpment of Geosciences, National Taiwan University, Taipei, Taiwan, ROC

* Corresponding author address. Prof. Xin Su, Center of Marine Geology, China University of Geoscienes, Beijing, China; E-mail: xsu@cugb.edu.cn
} 


\section{(Key words: Calcareous nannofossils, ODP Hole 1202B, Kuroshio Current, Pleistocene and Holocene)}

\section{INTRODUCTION}

The Kuroshio (Black Current) is the biggest western boundary surface current in the western Pacific. It plays an important role in transporting heat, mass, momentum, and moisture from the western Pacific warm pool to high latitudes in the North Pacific. The Kuroshio Current is characterized by its high temperature and salinity (Fan 1985; Yuan et al. 1998). The present Kuroshio Current passes between Taiwan and the southernmost part of the Ryukyu Island arc and then flows northeastward along the area between the trough and the outer edge of the East China Sea continental shelf (Fig. 1 and Fig. 2).

A number of previous study suggested that the Okinawa Trough changed from an opensea environment to a semi-enclosed marginal basin during the last glacial maximum (LGM, occured around $25-16 \mathrm{kaBP}$ with coldest period at $21 \mathrm{kaBP}$ ), because of a $120-\mathrm{m}$ sea level drop (Fairbanks 1989) and the emergence of a Ryukyu-Taiwan land bridge, which was suggested by Ujiié and Ujiié (1999) with a number of evidences. The Ryukyu-Taiwan land bridge prevented the Kuroshio Current from entering into the Okinawa Trough, as a result, the Kuroshio Current turned to the east at the southern end of the Ryukyu arc (Ujiié et al. 1991, Ujiié and Ujiie 1999) (Fig. 2). The inference made in the previous studies about the course changes of the Kuroshio Current was mainly based on plankton foraminiferal assemblages and $\delta^{18} \mathrm{O}$ data. Results of these studies regard Pulleniatina obliquiloculata as a good and sensitive indicator of the presence of the Kuroshio Current and high percentages of this species are restricted to the main route of the Kuroshio Current (Ujiié and Ujiié 1999, Jian et al. 2000).

In 2001, JOIDES Resolution of the Ocean Drilling Program sailed into Okinawa Trough, and drilled Site 1202 on the southern slope of the Okinawa Trough. One of the major paleoceanographic objectives for this Site is to obtain a high-resolution record about the history of the Kuroshio Current during the Quaternary.

Calcareous nannofossils from sediments of Hole 1202B were studied to obtain a highresolution nannofossil record of the change of the Kuroshio Current during the last glacial and the Holocene.

\section{MATERIALS AND METHODS}

\subsection{Materials}

\section{Surface Samples}

Sea floor surface sediments under the recent Kuroshio Current and its adjacent areas in the East China Sea were collected and studied.

A total of 14 surface sediment samples in 4 west-east transects extending from the East China Sea continental shelf to the Okinawa Trough from north to south were analyzed (Fig. 1). 


\section{ODP Site 1202}

During Leg 195, four holes were drilled: 1202A 1202B 1202C, and 1202D, penetrating to an unprecedented depth of 410 meters below seafloor (mbsf) in the southern Okinawa Trough. The entire 410-m section consists of rapidly deposited calcareous nannofossil-bearing dark gray silt and clay, intercalated with several layers of sandy turbidites. The oldest microfossils observed were $<127 \mathrm{ka}$ in age, implying that the sedimentation rate is at least $325 \mathrm{~cm} \mathrm{ky}^{-1}$. (Shipboard Scientific Party 2002).

This paper only presents results obtained by analyzing about 140 samples from the top interval of 0 - 60 mbfs from Hole 1202B $\left(24^{\circ} 48.2445^{\prime} \mathrm{N} 122^{\circ} 30.0077^{\prime} \mathrm{E}\right.$, water depth $1274.1 \mathrm{~m}$, Fig. 2). These samples contain very few to rare, moderately-preserved calcareous nannofossils, due to strong dilution of terrestrial materials.

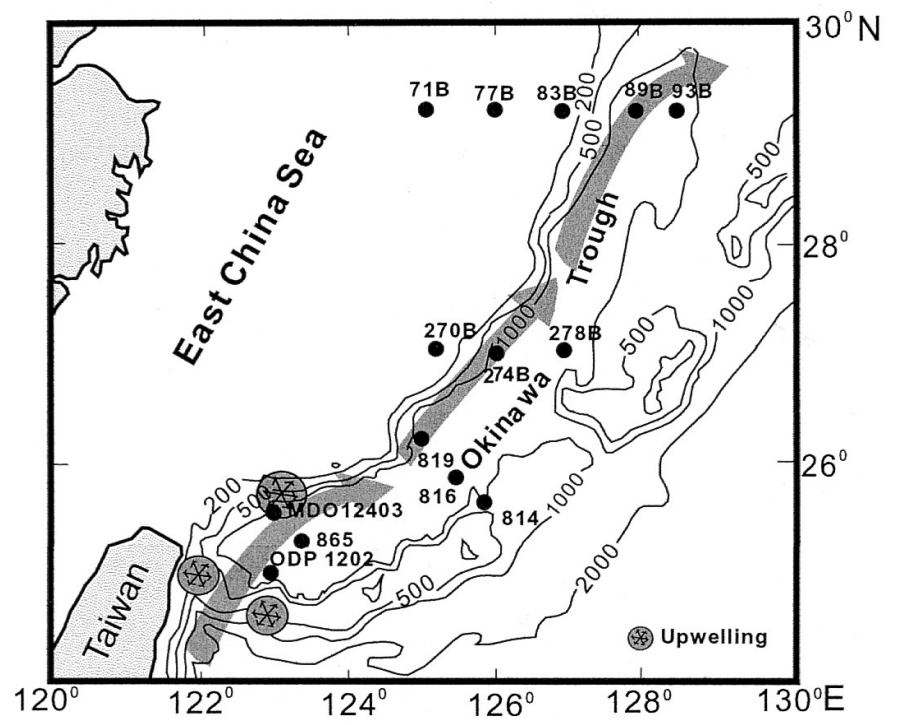

Fig. 1. The main route of the Kuroshio Current is given schematically after Shipboard Scientific Party (2002), and Ujiié and Ujiié (1999). The upwelling areas are after Shipboard Scientific Party (2002). Thin lines with numbers are water depth (m). Box cores EA03-71B, EA03-77B, EA03-83B, EA03-89B, EA03-93B, EA03-270B, EA03-273B, EA03-278B are briefly showed as 71B, 77B, 83B, 83B, 89B, 93B, 270B, 273B and 278B on this map; piston cores OT83-814, OT83-816, OT83-819 and OT83-865 are given as $814,816,819$ and 865 . 


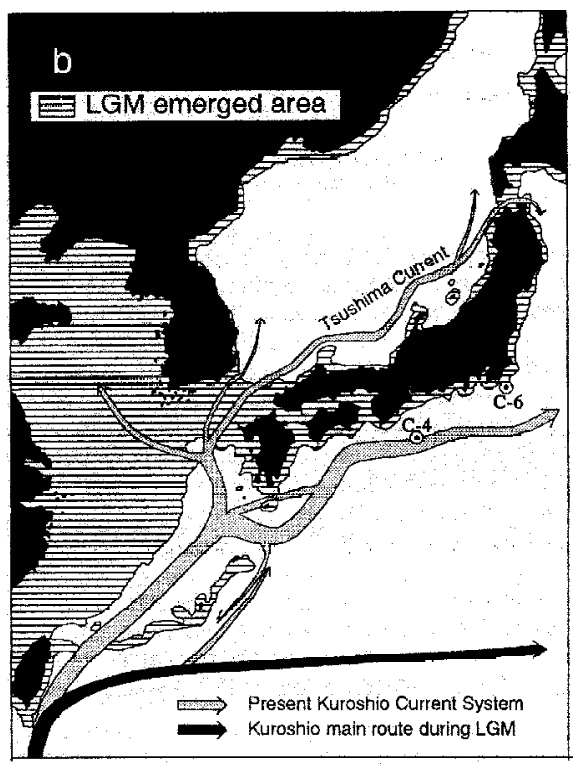

Fig. 2. Main route positions of the Kuroshio Current at the present and during the last glacial maximum suggested by Ujiié and Ujiié (1999).

\subsection{Methods}

Standard smear slides were prepared. Calcareous nannofossils were examined under a standard light microscope (Zeiss, Axioskop 2 plus) with crossed-nicols using transmitted light at 1000-times magnification.

Identification of Emiliania huxleyi, a very small sized coccolith species, was not only made by use of light microscope, but also by using scanning electronic microscope.

Previous study on North Atlantic nannofossils suggested that variation in nannofossil absolute abundance provided reliable evidence of links between coccolithophores and environmental changes (Su 1996). In order to obtain nannofossil absolute abundance from materials studied, we followed the semi-quantitative method suggested by Backman and Shackleton (1983). All individuals of selected nannofossil species were counted through a certain number of view fields, yielding measurements of abundance as "number of individuals on certain view fields". Backman and Shackleton (1983) used it to estimate absolute abundances of certain age-diagnostic marker species. It is a less time consuming, yet effective method for estimating the absolute abundance of calcareous nannofossils.

In this study, all individuals of calcareous nannofossil species observed on 10 to 20 viewing fields on smear slides were counted (at 1000× magnification). Two measurements of abundances were further derived from the counting data: 1) Absolute abundance presented as "number of nannofossils on 10 view fields", and relative abundance (percentage) of a given species in the assemblage by normalizing the total abundance to $100 \%$. 


\subsection{Stratigraphy}

\section{Biostratigraphic Zonation}

The microfossil biostratigraphy for sediments at ODP Site 1202 has been further examined during the postcruise study. The age-diagnostic marker for Martini's (1971) late Quaternary nannofossil Zone NN21, Emiliania huxleyi, occurs persistently throughout the sediment succession of $410 \mathrm{~m}$, suggesting that the recovered interval is younger than $0.26 \mathrm{Ma}$ (Berggren et al. 1995). Furthermore, pink-pigmented Globigerinoides ruber, a planktonic foraminifera species was absent in the $410 \mathrm{~m}$ interval. The datum of the last appearance of pink $G$. ruber in the Indo-Pacific Oceans was estimated at $127 \mathrm{ka}$ (Thompson et al. 1979; Lee et al. 1999). Both nannofossils and planktonic foraminifers suggest that the cored $410 \mathrm{~m}$ sediment sequence is younger than $127 \mathrm{ka}$.

\section{Oxygen Isotopic Stratigraphy and AMS ${ }^{14} \mathrm{C}$ Dates}

Stable oxygen isotope stratigraphy for Site 1202 was established by analyzing planktonic foraminifer Neogloboquadrina dutertrei and AMS ${ }^{14} \mathrm{C}$ dating for Hole $1202 \mathrm{~B}$ by Wei et al. (2005). Both data of isotopes and AMS ${ }^{14} \mathrm{C}$ dating were used in this study for stratigraphic correlation and age model, for example, the $\mathrm{AMS}{ }^{14} \mathrm{C}$ data were used for calibrating ages of samples.

This study presents result from samples in the upper $60.50 \mathrm{~m}$ sediment interval of Hole $1202 \mathrm{~B}$, an interval of an age of $13.32 \mathrm{ka}$, according to the data of AMS ${ }^{14} \mathrm{C}$ dating obtained by Wei et al. (2005). The bottom of the Holocene was placed at $10.0 \mathrm{ka}$ and at the depth of $35.3 \mathrm{mbsf}$ in Hole 1202B. Sedimentation rate for the Holocene was estimated as $353 \mathrm{~cm} \mathrm{ky}^{-1}$, and $759 \mathrm{~cm} \mathrm{ky}^{-1}$ for the late Pleistocene sediment interval from $35.3 \mathrm{mbsf}$ to $60.5 \mathrm{mbsf}$, that is, sedimentation rate in the glacial interval is more than two times higher than in the post glacial period for the interval studied.

\section{EVALUATION AND RESULTS}

\subsection{Calcareous Nannofossils from Surface Sediments}

\section{Nannofossil Species in the Surface Sediment Assemblages}

We recognized 20 calcareous nannofossil species from the surface sediments and from down-core sediments at ODP Hole 1202B. Three categories were divided according to the abundance of these species:

The $1^{\text {st }}$ category (abundant to common species): Emiliania huxleyi, Gephyrocapsa oceanica, Florisphaera profunda, characterized by their high absolute abundance (from 30 to 150 coccoliths on 10 view fields) and high relative abundance (from $20 \%$ to more than $80 \%$ ).

The $2^{\text {nd }}$ category (less common to few species): Calcidiscus leptoporus, Helicosphaera carteri, Rhabdosphaera clavigera, Syracosphaera spp., Reticulofenestra (small) spp., 
Umbilicosphaera sibogae, Umbellosphaera spp. with low absolute abundance (about 1 to 5 coccoliths on 10 view fields) or less than $3 \%$ in floral assemblage.

The $3^{\text {rd }}$ category (rare species): small Gephyrocapsa spp., Braarudosphaera begilowii, Neosphaera coccolithomorpha, Ceratolithus cristatus, Pontosphaera spp., Scapholitus fossilis, etc. They occur infrequently with very low abundance (less than $1 \%$ ).

\section{Ecology of Common Species}

The surface water of the Kuroshio Current is characterized by high temperature $\left(\sim 28^{\circ}\right.$ $29^{\circ} \mathrm{C}$ in the summer and $22^{\circ}-25^{\circ} \mathrm{C}$ in the winter), high salinity $(33.6-34.8 \%)$, and high flow speed (1.5 - $2 \mathrm{kt}$ ) (Hwang and Tang 1993). The Kuroshio Current is also characterized by its great depth ( 1000 m) (Fan 1985; Yuan et al. 1998).

Yang et al. (2001) observed that extant coccolithophorids in the Kuroshio main path are diverse and dominated by Umbellosphaeara with fairly abundant G. oceanica. On the other hand, the continental shelf water of the East China Sea was characterized by the dominance of E. huxleyi, G. oceanica (Cheng and Wang 1997; Yang et al. 2001).

In the $1^{\text {st }}$ category, $F$. profunda is a typical species of the lower photic zone. Its relative abundance was correlated with the nutricline depth in the equatorial open ocean. A shallower nutricline or low surface primary production would result in a lower abundance (Molfino and McIntyre 1990, Beaufort et al. 1997; Cheng and Wang 1998). On the other hand the abundance of this species in the marginal sea is related to water turbibidity (Ahagon et al. 1993). Takahashi and Okada (2000) proposed to use the ratio of small $(<2.5 \mu \mathrm{m})$ placoliths of Reticulofenestra and Gephyrocapsa against lower-photic species (including $F$. profunda) as a proxy of the nutrient condition in the water column; for example, an increase of the ratio indicates a shallower nutricline. In modern nannofossil assemblages in surface sediments from coastal and marginal seas along the western Pacific Ocean, abundant $(>15 \%) F$. profunda was found in open sea bathypelagic and abyssopelagic assemblages (Okada 1983). Cheng and Wang (1997) also showed abundance of $F$. profunda decreases dramatically from about $10 \%$ to less than $2 \%$ along a transect of Pearl River mouth, from $1000 \mathrm{~m}$ to $200 \mathrm{~m}$, in the northern South China Sea. E. huxleyi is a cosmopolitan species, adapting to a wide temperature range of $2-29^{\circ} \mathrm{C}$ (McIntyre and Bé 1967; Okada and Honjo 1975). G. oceanica prefers warm water and is abundant in warm marginal seas (Okada and Honjo 1975; Kleijne et al. 1989; Su 1989). In addition, an increase in the abundance of this species towards coastal region or upwelling area has been observed (Wang and Samtleben 1983). In surface sediments of China seas, $G$. oceanica dominances mainly in the inner shelf covered by coastal waters rich in nutrients (Cheng and Wang 1997).

In the $2^{\text {nd }}$ category, $R$. clavigera, $U$. sibogae, Umbellosphaera spp. prefer warm waters of tropic and transitional latitudes (McIntyrei and Bé 1967; Kleijine 1992). C. leptoporus is a cosmopolitan species (McIntyre and Bé 1967). However, various morphotypes of this species have been considered to be temperature related ecophenotypes (Kleijine 1992) and large sized variant of $C$. leptoporus $(>4 \mu \mathrm{m})$ in northern North Atlantic occurs only during the interglacial period (Baumann 1990). In our samples, mainly large sized forms of C. leptoporus were observed. In addition, $R$. clavigera and $C$. leptoporus live in the upper photic layer (Winter et 
al 1994).

Based on those previous studies and our nannofossil data obtained, we developed two ratio indices as paleoceanographic proxies for the area studied: (1) Ratio of $F$. profunda against F. profunda, E. huxleyi and G. oceanica (F-EG ratio) as a proxy of the Kuroshio Current, higher ratio $(>40 \%)$ being referred to the main route of the Kuroshio Current or intensification of the Kuroshio Current. (2) Ratio of G. oceanica against F. profunda, E. huxleyi and G. oceanica (G-FE ratio) as a proxy of near-coast environment. Furthermore we selected 4 warm water species, $R$. clavigera, $U$. sibogae, Umbellosphaera spp., C. leptoporus as additional indicators of the Kuroshio Current.

\section{Results from the Surface Sediment Study}

Both F-EG ratio and G-FE ratio, and total abundance of 4 warm water species in the 14 surface sediment samples from the eastern to southern Okinawa Trough were plotted in Figs. 3 and 4.

1) F-EG ratio as a proxy for the Kuroshio. In the two northern transects, the F-EG ratio is low (5\%) in surface nannofossil assemblages on the East China Sea continental shelf or its outer edge (Fig. 3). The ratio values increase southeastward within the Okinawa Trough and the flow area of the Kuroshio Current, as showed in Fig. 3. Generally, the F-EG ratio in surface nannofossil assemblages associated with the Kuroshio Current are higher than $15 \%$. These facts suggest that the F-EG ratio can serve as a nannofossil proxy for the Kuroshio Current, like foraminifer Pulleniatina obliquiloculata as an indicator of the Kuroshio Current (Ujiié and Ujiié 1999, Jian et al. 2000). For example, higher relative abundance ( $\geq 15 \%)$ of Pulleniatina is found only in surface sediments directly under the main route of the Kuroshio Current, whereas it is less than $15 \%$ in surface sediments out of the main route (Ujiié and Ujiié 1999). The reason for variation in the F-EG ratio among the assemblages in the northern and the southern cores is not clear at the present, however, the upwelling in the southern area (Fig. 1) might be one possible explanation for generally higher F-EG ratio there, because higher abundance of $F$. profunda is also related to higher surface primary production (Molfino and McIntyre 1990; Beaufort et al. 1997; Cheng and Wang 1998). The upwelling in the southern region should result in higher surface primary production than in the northern. MDO 12403 is located within one of the upwelling area, which might be the possible reason for the higher F-EG ratio (>60\%) at this than that (about 40\%) at ODP 1202 (Fig. 1).

2) G-FE ratio as an indicator of the coastal environment. High values of G-FE ratio (>30\%) were seen from all samples on the East China Sea continental shelf or near shore area (EA03-71B, EA03-77B, EA03-270B, Hole1202B). Therefore, the G-FE ratio can be used as a proxy of coastward or a near-coast environment.

3) Relative abundance of warm water species characterizing the Kuroshio. Generally, these species occur more abundantly in sediments under the Kuroshio Current than those from the East China Sea continental shelf or its outer edge (Fig. 4). However, Umbellosphaera spp. 

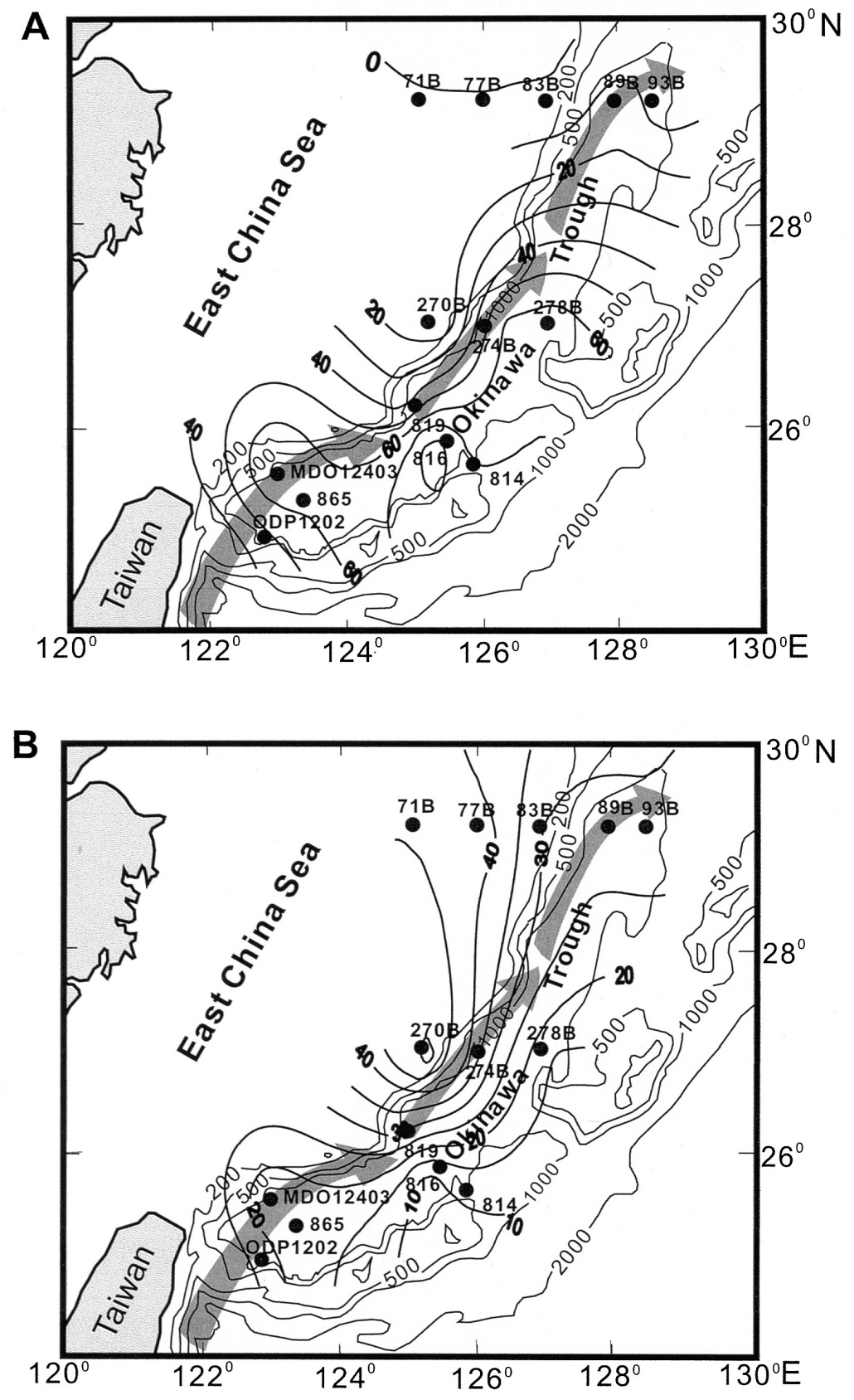

Fig. 3. Variation of the F-EG ratio (A) and G-FE ratio (B) for calcareous nannofossil assemblages in surface sediments from the East China Sea continental shelf and the Okinawa Trough. 

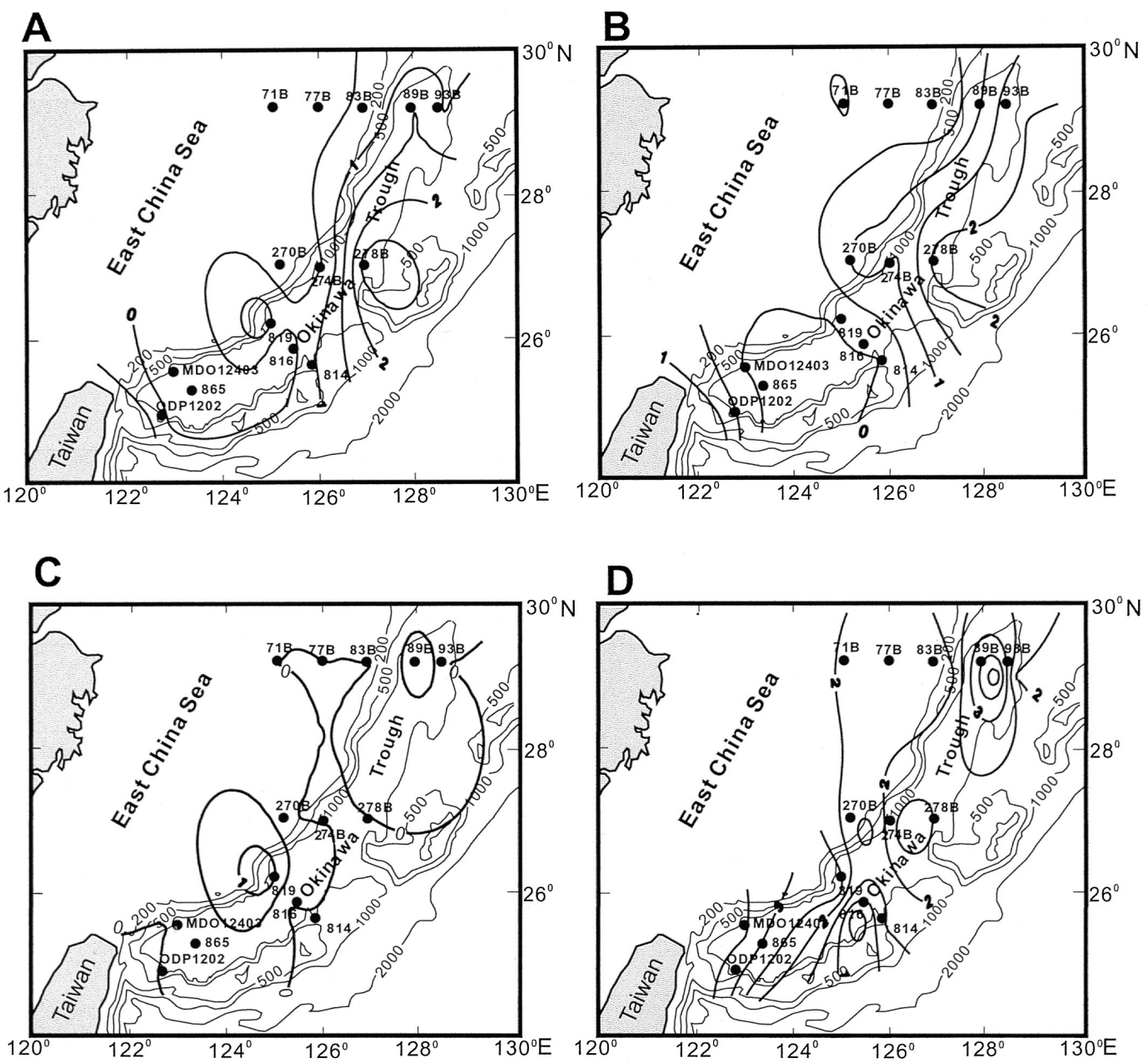

Fig. 4. Variation of relative abundances of less common species in surface sediments from the East China Sea continental shelf and the Okinawa Trough. A: Calcidiscus leptoporus, B: Rhabdosphaera clavigera, C: Umbellosphaera spp., D: Umbilicosphaera sibogae.

was not observed in the sample transect of EA03-270B-278B, nor $R$. clavigera in the transect of OT83-816-814. It is likely that the production of these species in the overlying waters of these sites has been extremely low that none of them were encountered on the $10-20$ viewing fields. Or, alternatively, these species are highly susceptible to dissolution (Wei et al. 1997) 
and therefore have already been dissolved in the oxidized organic-rich sediments. For these reasons, those warm water species were used only as supportive and secondary evidence for the presence of the Kuroshio Current. On the other hand, the absence of these species in a sample does not necessarily suggest a "cold" water condition due to the reasons mentioned above.

\subsection{Downhole Variation of Nannofossils in Hole 1202B}

Calcareous nannofossil assemblages in the top interval of 0 - 60 mbsf sediments from ODP Hole 1202B are composed of similar species as the surface assemblages. They are characterized by the dominance of 3 species, E. huxleyi, F. profunda, G. oceanica, and by the less common species, such as C. leptoporus, H. carteri, R. clavigera, Syracosphaera spp., Reticulofenestra (small) spp., U. sibogae, Umbellosphaera spp. Rare species in the assemblages are Gephyrocapsa (small) spp., B. begilowii, N. coccolithomorpha, C. cristatus, Pontosphaera spp., S. fossilis. A few of reworked species with ages from Miocene to Early Pleistocene were also observed, such as Discoaster spp., Reticulofenestra pseudoumbilicus, C. macintyrei ect.

The make-up of the nannofossil assemblages changes dramatically at the depth of 32 mbsf. Specifically, relative abundance of $F$. profunda in the upper interval of $0-32$ mbsf drops from $>15 \%$ to $<10 \%$ below 32 mbsf, it decreases further to $<5 \%$ or absent below 32 mbsf (Fig. 5a). Contrarily, relative abundance of G. oceanica increases significantly from about $20 \%$ above 32 mbsf to $>30 \%$ below 32 mbsf. (Fig. 5a). Fig. 5 b shows downhole variation in absolute abundances of E. huxleyi, F. profunda, G. oceanica. Similarly, the absolute abundances of $F$. profunda in the upper interval of $0-32 \mathrm{mbsf}$ is significantly higher (30 to 150 individuals on 10 view fields) above 32 mbsf than that (a few individuals or absent) below $32 \mathrm{mbsf}$ (Fig. 5b). This suggests that the dramatic change in abundance of $F$. profunda is not due to the influence of sedimentation rates (for example, dilution) below $32 \mathrm{mbsf}$, but resulted by a significant change of paleoceanographical environment. In addition, relative abundances of warm water species, including $R$. clavigera and $C$. leptoporus show relative higher values above 32 mbsf. Based on these changes, two calcareous nannofossil assemblages were distinguished: Assemblage I predominated by $F$. profunda together with E. huxleyi and G. oceanica above $32 \mathrm{mbsf}$; Assemblage II below $32 \mathrm{mbsf}$ is dominated by G. oceanica and E. huxleyi. A correlation of nannofossil record with $\delta{ }^{18} \mathrm{O}$ record of $N$. dutertrei in the same hole suggests that the significant change of the assemblages occurs in the very early period of the marine oxygen isotope Stage 1, at $9.5 \mathrm{ka}$ to $9 \mathrm{ka}$ in the early Holocene (Fig. 5b).

\subsection{Temporal Variation of Ratios F-EG and G-FE and the Kuroshio Current}

The results from surface sediment nannofossil assemblages suggested that the F-EG ratio can serve as a nannofossil proxy for the Kuroshio Current, like foraminifer Pulleniatina obliquiloculata as an indicator of the Kuroshio Current in previous studies, while high ratios G-FE indicate a near-coast environment. Down-hole ratios of F-EG and G-FE at Hole 1202B were plotted against age and with the $\delta{ }^{18} \mathrm{O}$ profile of $N$. dutertrei in Fig. 6. 
(A)

ODP Hole 1202B

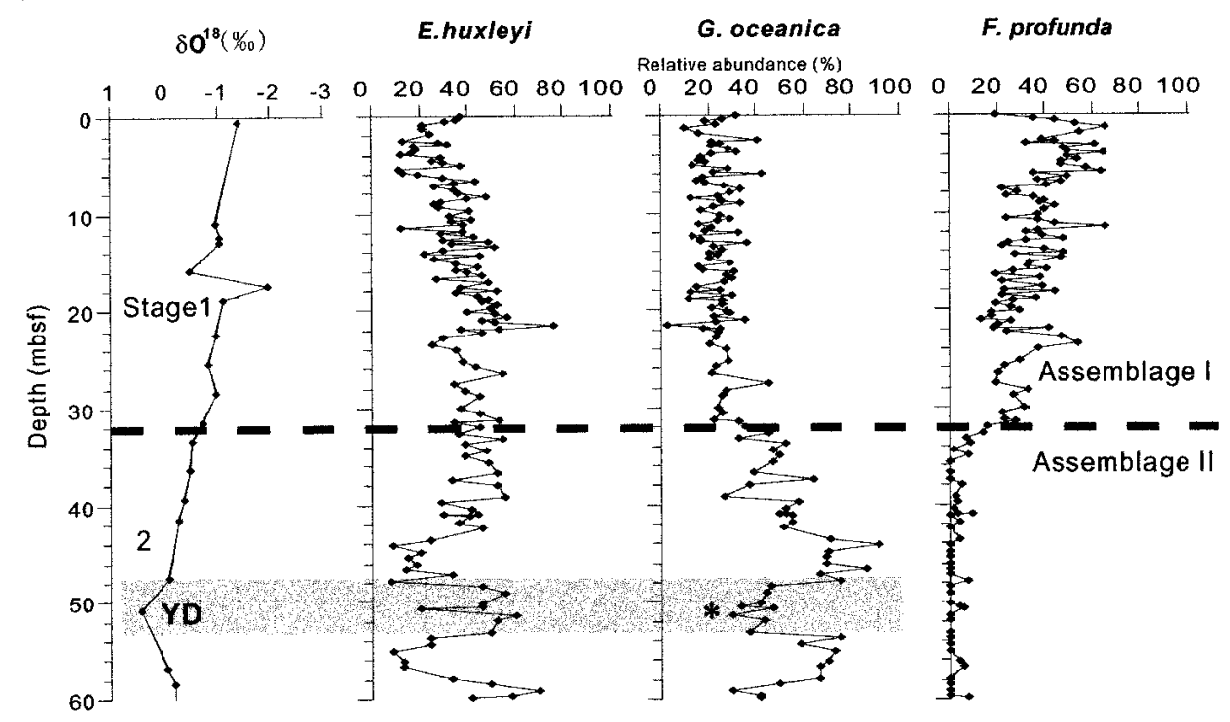

(B)

ODP Hole 1202B

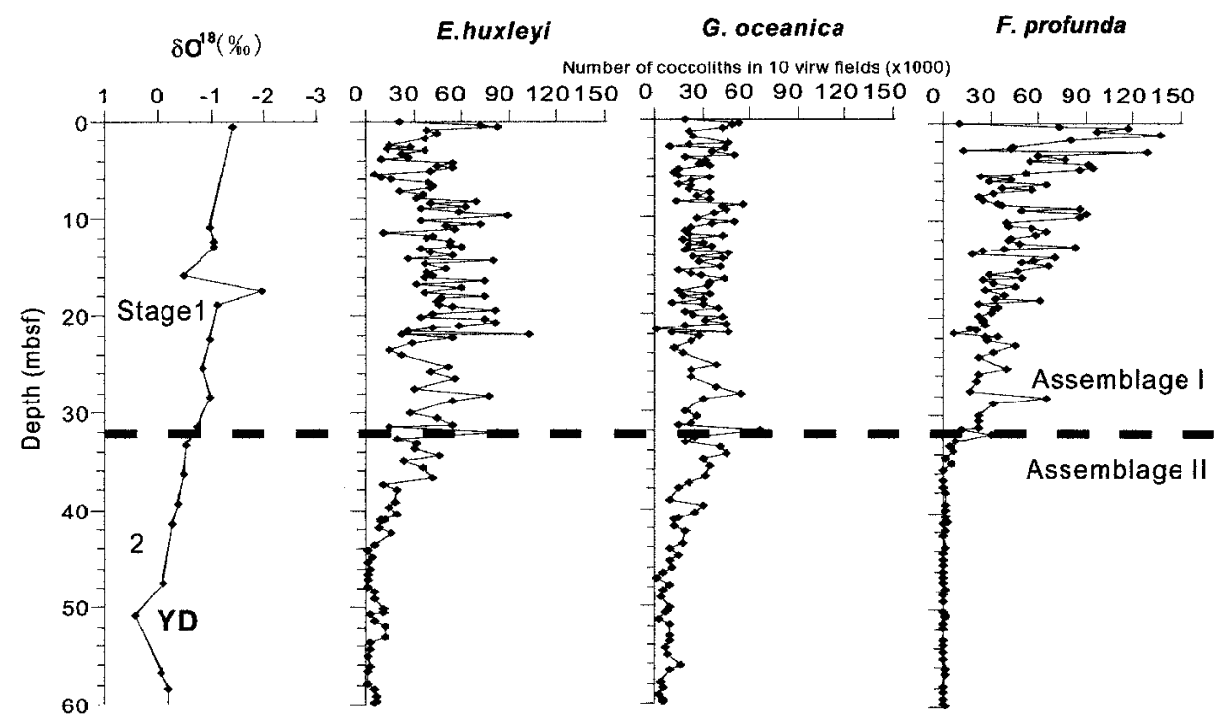

Fig. 5. Down-hole variations of relative abundance (A) and absolute abundance (B) of 3 dominant species and $\delta{ }^{18} \mathrm{O}$ of $N$. dutertrei at ODP Hole 1202B plotted against depths. YD represents the Younger Dryas event. The star symbol in (A) shows the warm water G. oceanica reduces production during the cold Younger Dryas event (See text). 


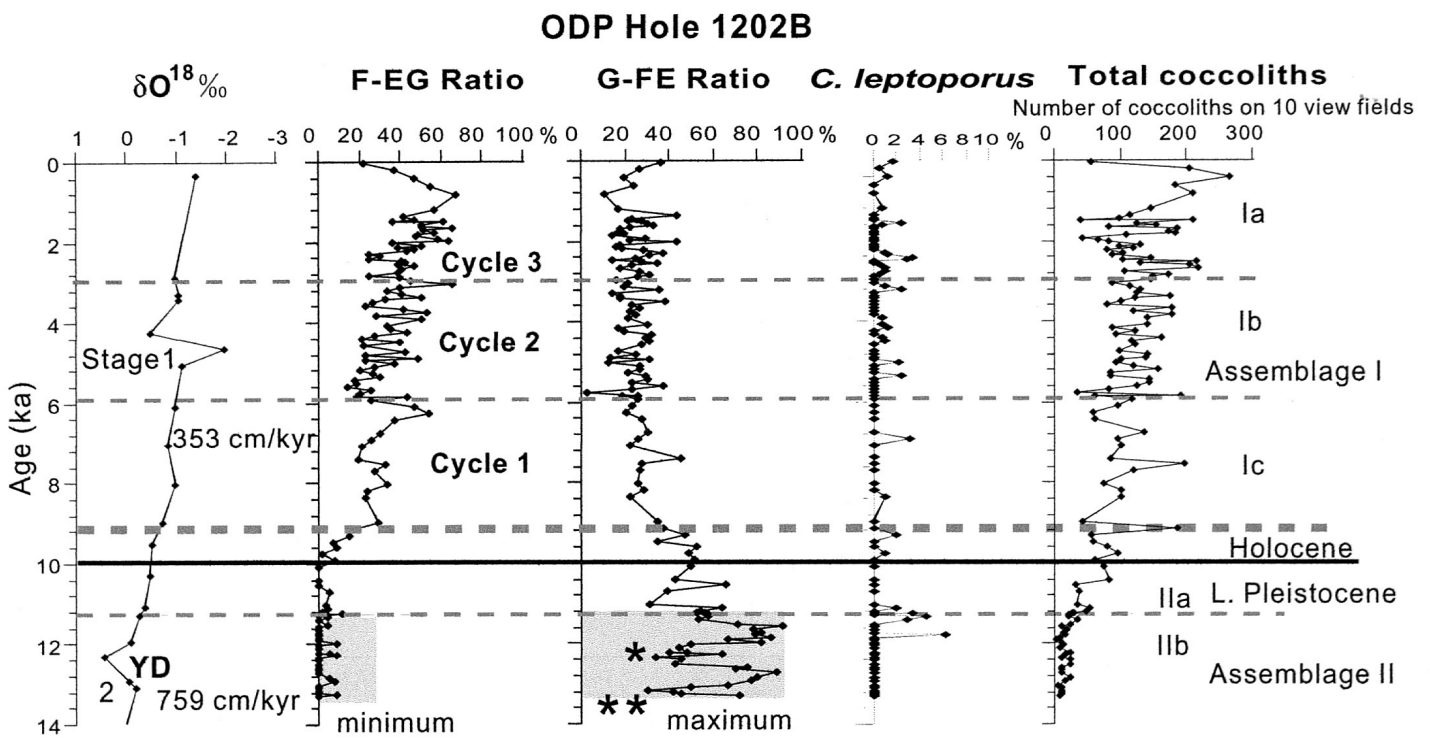

Fig. 6. Down-hole variation of the F-EG ratio, G-FE ratio and $\delta^{18} \mathrm{O}$ of $N$. dutertrei at ODP Hole 1202B plotted against age. In addition, relative abundance of a warm water species, $C$. leptoporus, and total coccoliths were plotted. The star symbols mark two low values of G-FE ratio (See explanation in the text). $353 \mathrm{~cm} \mathrm{ky}^{-1}$ and $759 \mathrm{~cm} \mathrm{ky}^{-1}$ are sedimentation rates for the Holocene and the Upper Pleistocene interval studied.

\section{Hole 1202B and the Kuroshio Current during the Transition of the Pleistocene and}

\section{Holocene}

As characterizing with very low values, the minima of the F-EG ratio in Hole 1202B were observed during the transition between the latest Pleistocene and early Holocene (Assemblage I), varying from 0 to $5 \%$. These values are similar to those in the surface assemblages from EA03-71B and EA03-83B, lying under a water depth of $<200 \mathrm{~m}$ far away from the Kuroshio Current. It implies that the coccolith assemblages at Hole 1202B prior to the $9 \mathrm{ka}$ were not influenced by the Kuroshio Current. In other words, the Kuroshio Current did not flow nearby above Site 1202 during that time.

In contrast, the values of the G-FE ratio were very high (> 40\%) in Assemblage II. The highest values of the G-FE ratio (60 - 90\%) were found around 13 to $11 \mathrm{kyr}$ ago, corresponding to the Younger Dryas cold event, which was a sudden cold climate period lasting for about 1100 - 1300 calendar years during the final deglaciation of the Pleistocene and it interrupted the warm interval of the Allerød period and was followed by the Preboreal period of the Holocene (Kallel et al. 1988). This suggests also that Hole 1202B in that time was located much closer to the coast than the present, partly as a result of sea level drop, about $60 \mathrm{~m}$ lower than 
the present (Fairbanks 1989). In addition, the shallow water above this area probably also implies that this area was not subsided as deep as its today's position which was seen as a result of the recent phase of extension of the Okinawa Trough in the late Pleistocene ( 0.1 Ma) (Furukawa et al. 1991).

Based on variation in absolute abundance of total nannofossils in sediment samples of Hole 1202B, two sub-assemblages (IIa and IIb) were further recognized (Fig. 6). Values of total coccoliths in the sub-assemblage IIb were the lowest for the entire studied interval, probably resulted by reduce of productivity in association with the cold Younger Dryas, or as a result of strong dilution due to high sedimentation rates in this period (Wei et al. 2005). The lowest G-FE ratio values (about 30\%) in IIb can be seen and marked by star symbols in Fig. 6. Similar decrease in relative abundance of G. oceanica during the Younger Dryas period can be observed and marked by a star symbol in Fig. 5a. G. oceanica prefers warm water and its productivity reduce in cold water, therefore, its production reduced during the Younger Dryas period. The warm water species C. leptoporus is absent during the Younger Dryas (Fig. 6), indicating cold water in this area during this period. On the other hand, E. huxleyi is a cosmopolitan species and can adapt to a wide temperature range of $2-29^{\circ} \mathrm{C}$, thus this species became the only dominant species during the Younger Dryas period (Fig. 5a). Values of total coccolith abundance increased in sub-assemblage IIa, by two times of that in sub-assemblage IIb. This indicates an increase of coccolith productivity, probably caused by surface water warming after the Younger Dryas.

\section{Re-entering of the Kuroshio Current into the Okinawa Trough at $\sim 9$ ka}

The F-EG ratio increases dramatically from $5 \%$ to about $30 \%$ during time from $9.5 \mathrm{ka}$ to $9 \mathrm{ka}$, in very early Holocene period (Fig. 6). The value (30\%) is even higher than the recent value $(20 \%)$ found in the surface sample of Hole 1202B. This suggests the increase of F. profunda was associated with the returning of the Kuroshio Current into the Okinawa Trough, probably because of sea-level rising. Meanwhile, the G-FE ratio decreased notably from $>50 \%$ to $20 \%$ at the same time and then it remained at a quasi-stable value of about $20 \%$ through the Holocene. This implies that the distance from Hole 1202B to coast has been similar to today's situation ever since 9 ka.

\section{Variability of the Kuroshio Current during the Holocene}

During the Holocene, the F-EG ratio shows an increasing trend towards the late Holocene, except for the last $800 \mathrm{yr}$ when it reduced notably from $~ 70 \%$ to $20 \%$ (Fig. 6).

Three sub-assemblages (Ia, Ib, Ic) from late Holocene to early Holocene were recognized, showing as 3 long-term cycles (Fig. 6). Each cycle begins with a gradual increase of the F-EG ratio and it accentuated to a maximum towards the end before a drastic drop. Cycle 1, the earliest one, runs from $\sim 9.5 \mathrm{ka}$ to $\sim 5.5 \mathrm{ka}$, the second from $\sim 5.5 \mathrm{ka}$ to $\sim 2.5 \mathrm{ka}$, and the last, Cycle 3, begins from $\sim 2.5 \mathrm{ka}$ and then shows a significant decrease for the last $800 \mathrm{yr}$. These cycles are of a periodicity of $\sim 3000 \mathrm{yr}$. Overall, the maximal in each of three cycles show a cascade array of increasing peaks (Fig. 6). 
Our knowledge of periodicity of the Kuroshio Current at millennial scale during the Holocene is limited. Xu and $\mathrm{Su}$ (1987) studied nannofossils from cores OT83-819 and OT83-865 in the Okinawa Trough and recognized 3 long-term warm-cold cycles based on variation in nannofossil species diversity. These cycles were used for Holocene stratigraphic subdivision: a warm Prenorth stage, a cold North stage, the maximum warm Atlantic stage, a cold Subnorth stage and a warm Subatlantic stage, being well correlated with climate variation indicated by spore and pollen data from the Yellow Sea and Japan. Oda and Takemoto (1992) studied planktonic foraminifers from seas off the Pacific coasts of Japan, and suggested 2 shifts of the axis of the Kuroshio Current from northwestward to southwestward in the time intervals of $10 \mathrm{ka}$ to $9 \mathrm{ka}$, and $9 \mathrm{ka}$ to $6 \mathrm{ka}$, respectively. Thereafter the Kuroshio Current keeps the similar course as the recent one since $5 \mathrm{ka}$. Jian et al. (2000) studied Holocene planktonic foraminifers and $\delta{ }^{18} \mathrm{O}$ from the Okinawa Trough, found periodic ( 1500 yr and $\sim 700-800 \mathrm{yr}$ ) variation of the Kuroshio Current. They attributed the periodicity to the $1500 \mathrm{yr}$-cycle in oceanic thermohaline circulation (Wunsch 2002) during the Holocene.

Those previous studies proposed three kinds of assumptions for the millennial periodicity of various records related to the Kuroshio Current during the Holocene: (1) Variation in microfossil productivity probably due to fluctuations of surface water temperatures caused by climatic fluctuations; (2) variation in microfossil productivity was caused by intensification or weakening of the Kuroshio Current as a result of oceanic thermohaline circulation; (3) and spatial sifting of the Kuroshio Current main axis or front movement. At the present, we are unable to differentiate these arguments. Further studies by exploring multi-proxies and in a much wider area along the Kuroshio Current would be necessary.

\section{CONCLUSION S}

A study of nannofossils of ODP Hole 1202B and surface sediments from the Okinawa Trough and East China Sea allows us to infer the variation of the Kuroshio Current, during the last $14 \mathrm{kyr}$.

Results from 14 surface nannofossil samples demonstrated that F-EG ratio is $>15 \%$ in the assemblage related to the Kuroshio Current, whereas it is very low $(<10 \%)$ in sediments off the current. Thereby the F-EG ratio was a nannofossil proxy for the Kuroshio Current. On the other hand, high ratios of G-FE (>30\%) were seen from all samples on the East China Sea continental shelf or from the near-coast cores.

Extreme low values of F-EG ratio together with very high G-FE ratio at Hole 1202B in sediments deposited prior to 9 ka suggest that the main path of the Kuroshio Current did not enter into the southern Okinawa Trough during $14 \sim 9 \mathrm{ka}$. The event of re-entering of the Kuroshio Current was clearly recorded by the dramatic increase of the F-EG ratio and the concomitant decrease in G-FE ratio at about $9 \mathrm{ka}$. Furthermore, variation of the F-EG ratio during the Holocene indicates 3 long term and intensified cycles of Kuroshio variation.

Acknowledgments This research used samples and data provided by the Ocean Drilling Program (ODP). ODP is sponsored by the U.S. National Science Foundation (NSF) and participating countries under the management of Joint Oceanographic Institutions (JOI), Inc. Core 
MD 012403 was provided by IMAGE program. Box cores from the Okinawa Trough were provided by Dr. Shi Xuefa and Dr. Chen Zhenbo from the First Institute of Oceanography of National Oceanography Bureau. Funding for this research was provided by the China Natural Sciences Foundation (Grant No. 40246002) to Xin Su and by the National Science Council ( NSC90-2611-M-002-005-ODP ) to Kuo-Yen Wei.

\section{REFERENCES}

Ahagon, N., Y. Tanaka, and H. Ujiié, 1993: Florisphaera profunda, a possible nannoplankton indicator of late Quaternary changes in seawater turbidity at the northwestern margin of the Pacific. Marine Micropaleont., 22, 255-273.

Backman, J., and N. J. Shackleton, 1983: Quantitative biochronology of Pliocene and Early Pleistocene calcareous nannofossils from the Atlantic, Indian and Pacific Oceans. $M a-$ rine Micropaleont., 8, 141-170.

Baumann, K. H., 1990: Veränderlichkeit der Coccolithophorididenflora des Europäishcen Nordmeeres im Jungquartär, Ber. Sonderforschungsbereich 313, Univ. Kiel 22, 146pp.

Beaufort, L., Y. Lancelot, P. Camberlin, O. Cayre, E. Vincent, F. Bassinot, L. Labeyrie, 1997: Insolation cycles as a major control of equatorial Indian Ocean primary production. Science, 278, 1451-1454.

Berggren, W. A., D. V. Kent, C. C. Swisher, III, and M. P. Aubry, 1995: A revised Cenozoic geochronology and chronostratigraphy. In: Berggren, W. A., D. V. Kent, M. P. Aubry, and J. Hardenbol, (Eds.), Geochronology, Time Scales and Global Stratigraphic Correlation. Spec. Publ. Soc. Econ. Paleontol. Mineral. (Soc. Sediment. Geol.), 54, 129-212.

Cheng, X. and Wang, P. 1997: Controlling factors of coccolith distribution in surface sediments of the China Sea: marginal sea nannofossil assemblages revisited. Marine Micropaleont., 32, 155-172.

Cheng, X. and Wang, P., 1998: Variations in late Quaternary upper ocean Structure of Okinawa Trough: A nannofossil approach. Sci. China, Ser. D., 41, 290-296.

Fan, K. L., 1985: CTD Measurements in the seas around Taiwan During 1977-1983. Spec. Publ. Inst. Oceanogr., Natl. Taiwan Univ. (Taiwan), 51.

Fairbanks, R. G., 1989: A 17,000-year glacio-eustatic sea level record: influence of glacial melting rates on the Younger Dryas event and deep-ocean circulation. Nature, 342, 637-642.

Furukawa, M., H. Tokuyama, S. Abe, A. Nishizawa, and H. Kinoshita, 1991, Report of DELP 1988 cruises in the Okinawa trough. Bull. Earthquake Res. Inst. Univ. Tokyo, 66, $17-$ 36.

Huang, S. J., and T. Y. Tang, 1993: CTD data bank data report. Regional Instrument Center R/V Ocean Researcher I: Taipei (Nat. Sci. Counc.).

Jian, Z., P. Wang, Y. Saito, J. Wang, U. Pflaumann, T. Oba, and X. Cheng, 2000: Holocene variability of the Kuroshio Current in the Okinawa Trough, northwestern Pacific Ocean. Earth Planet. Sci. Lett., 184, 305-319. 
Kallel, N., L. D. Labeyrie, M. Arnold, H. Okada, W. C. Dudley, and J. C. Duplessy, 1988: Evidence of cooling during the Younger Dryas in the western North Pacific. Oceanol. Acta, 11, 369-375.

Kleijne, A., D. Kroon, and W. Zevenboom, 1989: Phytoplankton and foraminiferal frequencies in northern Indian Ocean and Red Sea surface waters, Proc. Snellius II Symp, Neth., J. Sea, Res. 24, 531-539.

Kleijine, A. 1992: Extant Rhabdosphaeraceae (coccolithophorids, class Prymnesiophyceae) from the Indian Ocean, Red Sea, Mediterranean Sea and North Atlantic Ocean. Scripta Geologica, 100, 1-63

Lee, M. Y., K. Y. Wei, and Y. G. Chen, 1999: High resolution oxygen isotope stratigraphy for the last 150,000 years in the southern South China Sea: Core MD972151.Terr. Atmos. Ocean. Sci., 10, 239-254.

Martini, E., 1971: Standard Tertiary and Quaternary calcareous nannoplankton zonation. In: Farinacci, A., (Ed.), Proc. 2nd Int. Conf. Planktonic Microfossils Roma: Rome (Ed. Tecnosci.) 2, 739-785.

McIntyre, A., and A. W. H. Bé, 1967: Modern coccolithophoridae of the Atlantic Ocean. I. Placoliths and cyrtoliths. Deep-Sea Res., 14, 561-597.

Molfino B., and A. McIntyre, 1990: A. Precessional forcing of nutricline dynamics in the Equatorial Atlantic. Science, 249, 766 769

Oda, M., and A. Takemoto, 1992: Planktonic foraminifera and paleoceanography in the domain of the Kuroshio Current around Japan during the last 20,000 years. Quat. Res., 31, 341-357.

Okada H., and S. Honjo 1975: The distribution of oceanic coccolithophorids in the Pacific. Deep-Sea Res., 20, 355-374.

Okada, H., 1983: Modern nannofossil assemblages in sediments of coastal and marginal seas along the western Pacific Ocean. Utrecht Micropaleontol. Bull., 30, 171-187.

Shipboard Scientific Party 2002. Site 1202. In Salisbury, M.H., Shinohara, M., Richter, C., et al., Proc. Init. Repts. 195 1-46, [CD-ROM]. Available form: Ocean Drilling Program, Texas A\&M Unive., College Station, TX 77845-9547, USA.

Su, X., 1989: Calcareous nannoflora, In Hao et al., Quaternary Microbiotas and their Geological Significance from Northern Xisha Trench of South China Sea, China University of Geosciences Press, 52-57 (in Chinese with English abst.).

$\mathrm{Su}$, X., 1996: Development of Late Tertiary and Quaternary coccolith assemblages in the Northeast Atlantic. GEOMAR Rep., 48. 119pp.

Takahashi, K., and H. Okada, 2000: The paleoceanography for the last 30,000 year in the southeastern Indian Ocean by means of calcareous nannofossils. Marine Micropaleont., 40, 83-103.

Thompson, P. R., A. W. H. Bé, J. C. Duplessy, and N. J. Shackleton, 1979: Disappearance of pink-pigmented Globigerinoides ruber at $120,000 \mathrm{yr}$ BP in the Indian and Pacific Oceans. Nature, 280, 554-558.

Ujiié, H., Y. Tanaka, and T. Ono, 1991: Late Quaternary paleoceanographic record from the middle Ryukyu Trench slope, northwest Pacific. Marine Micropaleont., 18, 115-128. 
Ujiié, H., and Y. Ujiie, 1999: Late Quaternary course changes of the Kuroshio Current in the Ryukyu arc region, northwestern Pacific Ocean. Marine Micropaleont., 37, 23-40.

Wang, P., and C. Samtleben, 1983: Calcareous nannoplankton in surface sediments of the East China Sea. Marine Micropaleont., 9, 249-259.

Wei, K. Y., T. N. Yang, and C. Y. Huang, 1997: Glacial-Holocene calcareous nannofossils and paleoceanography in the northern South China Sea. Marine Micropaleont., 32, 95114.

Wei, K. Y., H. S. Mii, and C. Y. Huang, 2005: Age model and oxygen isotope stratigraphy of Site ODP 1202 in the Southern Okinawa Trough. Terr. Atmos. Ocean. Sci, 16, 1-17.

Winter, A., R. W. Jordan, and P. H. Roth, 1994: Biogeography of living coccolithophores in ocean waters, in Coccolithophores, In: Winter, A., and W.G. Siesser, (Eds.) Cambridge Unive. Press, Cambridge 161-178.

Wunsh, C., 2002: What is the thermohaline circulation?. Science, 298, 1179-1181.

Xu, Y., and X. Su, 1987: Holocene calcarous nannofloral assemblage from the Okinawa Trough with discussion on Holocene paleoclimate. Acta Micropalaeontol. Sinica, 4, 335-344. (in Chinese with English abst.).

Yang, T. N., K. Y. Wei, and G. C. Gong, 2001: Distribution of coccolithophorids and coccoliths in surface ocean off northeastern Taiwan. Bot. Bull. Acad. Sinica, 42, 287-302.

Yuan, Y., Y. Liu, C. T. Liu, and J. Su, 1998: The Kuroshio east of Taiwan and the currents east of the Ryukyu Islands during October of 1995. Acta Oceanol. Sinica, 17, 1-13. 